\title{
多脚ロボットの回転歩容による移動適用範囲の拡大
}

\author{
上川健 司*1 新 井 健 生 ${ }^{2}$ 前 泰 志 $* 2$ \\ 田窪 朋 仁*2 井上 健 司*3
}

\section{Expansion of Movable Area of Multi Legged Robot by Rotational Gait}

Kenji Kamikawa*1, Tatsuo Arai*2, Yasushi Mae*2, Tomohito Takubo*2 and Kenji Inoue*3

\begin{abstract}
This paper proposes a new locomotion algorithm of narrow scaffold. We have developed a limb-mechanism robot. The limb can move on a large working area, it can be used as an arm and a leg. ASTERISK Robot system has six limbs that radiate out in six directions. This robot system has the rotational symmetry, therefore, the posture is equivalent even if the robot body rotates. By using this feature, we propose a new movement algorithm "rotational gait" that the robot rotates like a wheel. The rotational gait can be applied to the robot that hanging on a cable, moving on narrow shelf of a cliff, and walking in a narrow space by the same algorithm. The operation and effectiveness of these algorithms were verified by the experiment. The movement algorithm is easy pattern operation that keeps stable state at all periods. And the robot can move without doing a high-speed real-time processing.
\end{abstract}

Key Words: Limb-mechanism, Rotational Symmetry, Narrow Scaffold, Hanging on a Cable, Rotational Gait

\section{1.はじめに}

近年，地震や洪水のような自然災害をはじめとした様々な災 害が増加しており, 被災地では被災者に対する迅速な救援活動 が必要である。しかしながら被災者を探索あるいは救助するこ とには危険が伴うことから，このような危険作業にロボットや 遠隔操作機器を使用することが望まれている $[1] 〜[3]$. 不整地 や瓦礫などの堆積した環境での移動にはクローラや車輪を用い るロボットだけではなく多脚ロボットも提案されている [4] [5]. もし同一のロボットで不整地だけではなく傾斜地形や壁, 天井 など様々な環境を移動して作業することが可能であれば，災害 緊急時のみならず平時における建築構造物の狭盆部の検査など, その適用分野は飛躍的に拡大すると考えられる（Fig. 1).

腕・脚を持つ移動作業ロボットはこれまでも, 多脚歩行ロボッ トとしての不整地移動動作のみならず，脚の一部を物体の把持 などの作業に用いながら残りの脚で歩行動作を行う移動作業動 作 [6], 脚だけではなくロボット本体を接地することにより高さ 方向に低い狭盆部を移動する動作 [7], また, 水平に限らず移動

\footnotetext{
原稿受付 2009 年 8 月 9 日

${ }^{* 1}$ 日立造船株式会社

$* 2$ 大阪大学大学院基礎工学研究科

$* 3$ 山形大学大学院理工学研究科

${ }^{* 1}$ Hitachizosen Corporation

${ }^{* 2}$ Graduate School of Engineering Science, Osaka University

${ }^{* 3}$ Graduate School of Science and Engineering, Yamagata University

口本論文は提案性で評価されました。
}

適用範囲を拡大し, ウインチを用いた斜面移動 [8] や，階段など の段差 [9], 梯子の昇降動作 [10], など, 様々な形態・移動方法 が示されている。 このような多脚ロボットの一つとしてリムメ カニズムが提案されている，リムメカニズムとは，腕にも脚に も利用できる複数の “リム”と呼ばれる腕脚機構を備えた多脚 ロボットシステムである、筆者らはこれまでに 6 本のリムをロ ボット本体から放射状に配置し, 全周方向に対称かつ上下方向 にも対称な動作範囲を持つ, アスタリスクロボットシステムを 提案している [11]. このアスタリスクロボットシステムを用い て平地や凹凸のある不整地での全方向移動，2 本のリムを腕と して用いて物体把持しながらの移動作業, 格子状に足場を配し

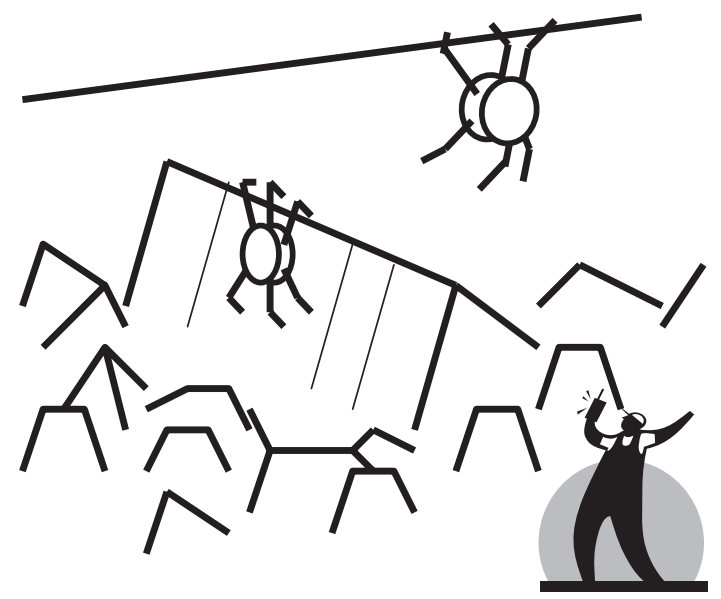

Fig. 1 Robots work at a disaster area 


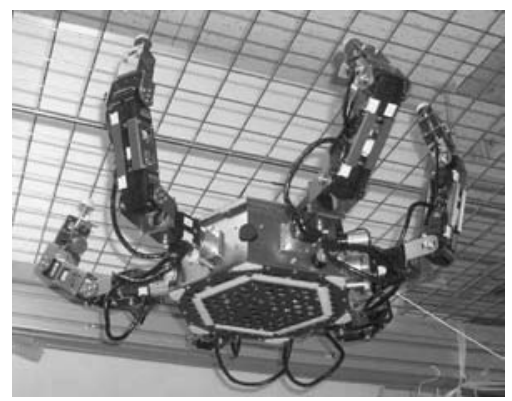

Fig. 2 Hanging on a grid ceiling of ASTERISK

た天井での懸垂移動など, 同一形状のロボットを用いて移動作 業適用範囲の拡大を提案, 実証してきた (Fig. 2).

本報告ではロボットが二次元平面内での移動だけではなく, 狭 㜝部や空間に張られたケーブルなどロボットを支える足場が極 端に狭くまた支持脚の可動範囲も狭いためにロボットの姿勢変 化が困難な状態での移動を可能とするための, ロボット本体を 回転させて支持脚を順次入れ換えながら移動する歩容を「回転 歩容 (rotational gait)」として新たに提案する。 また提案する 移動方法は, 動作の各時点で安定状態を保ち実時間制御を必要 としない準静的なパターン動作とした。 そしてこれらの移動ア ルゴリズムを実際のアスタリスクロボットに実装しこれを実証, 有効であることを確認した.

\section{2. 回転歩容アルゴリズム}

2.1 リムメカニズムとアスタリスクロボットシステム

リムメカニズムとは, 多脚・多腕ロボットシステムにおいて, 腕と脚の機能を統合した「リム」と呼ばれる腕脚機構を持つロ ボットシステムである. 同一のリムを用いて, 脚としての歩行 や腕として物体の把持を行うため, リムは通常の脚機構に比し て広い動作範囲を持っている。

本報告で用いるアスタリスクロボットシステムは, リムメカ ニズムの一つの形態として提案されているもので, Fig. 3 (a) に示すようにロボット本体から放射状に 6 本のリムを配置し中 心軸まわりに回転対称性を持ち, Fig. $3(\mathrm{~b})$ のように本体上下方 向についても対称な形状である. 各リムは本体側から順に J1, J2, J3 の 3 個のアクチユエータを持っており各リムの動作範囲 も対称となっている。アスタリスクロボットシステムはリムの 動作範囲が非常に広いことから, 同じ形状のロボットで移動作 業の様々な用途に適用できる沉用性を持つ。

本報告ではリムを移動のための脚として用いることから，以 降は「リム」を「脚」と記述する.

\section{2 アスタリスクロボットによる回転歩容の提案}

一般的な多脚ロボットの移動時の脚の接地範囲は, 接地面に 投影されるロボット本体から伸びる脚の動作範囲により決まる ものでありロボット本体に比べ広い領域となっている。しかし ながら狭盆環境での移動やケーブルを足場とした移動などを想 定した場合には移動方向に伸びる狭い接地範囲しか取れない場 合が想定される（Fig.4）.

このような条件ではロボット本体を立てて接地面に面する側 の脚による接地姿勢をとることができても, 支持脚の接地間隔

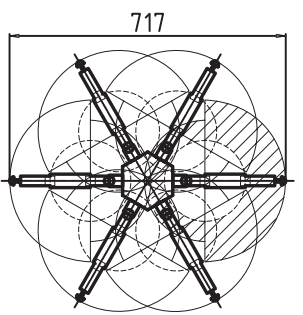

(a)

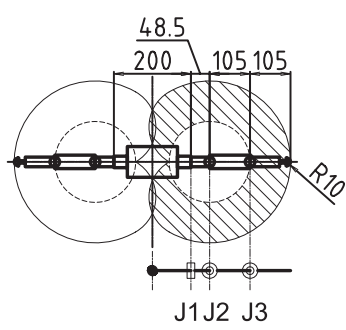

(b)
Fig. 3 Workspaces of ASTERISK

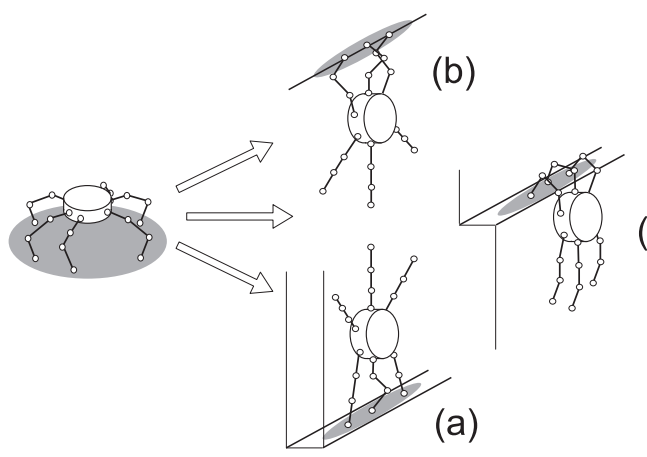

(c)

Fig. 4 Concept of rotational gait on narrow scaffolds

が狭く脚の動作範囲も大きく取れないため脚の踏み換えによる 移動は難しい．このような場合に，アスタリスクロボットシス テムが持つ回転対称性すなわちロボットが回転してもロボット が置かれた環境側から見ると回転前と同等な姿勢であるという 特徴を活かして，ロボット本体を車輪の様に回転させることに より脚を順次踏み換えて移動する方法を提案する。

次章以降に回転歩容の具体的な実証例として,（a）狭险部の 通過移動，（b）水平に張り渡したケーブルを足場とする懸垂移 動, そして（c）棚状の狭隘足場での移動を述べる. これら 3 種 類の異なる移動環境に適用する回転歩容アルゴリズムは, 接地 対象が異なるため脚のロボットの接地姿勢はそれぞれ違うもの の脚の移動順序としては同一のアルゴリズムであり, 簡単なパ ターン動作の繰り返しで移動することができる。また提案する 回転歩容は, 動作の各時点で安定状態を保ちながら動く, 実時間 制御を必要としない準静的なパターン動作とすることができる.

\section{3. 狭隘通路の移動}

狭隘足場の移動を想定する場合, 災害現場での瓦礫の間や建 築物の隙間などの幅方向に狭い狭隘通路（両側を壁に挟まれた 隙間もしくは片側が壁面の棚部）での移動が考えられる.

本章では支持脚がロボット本体の下側にありロボットを側転 させることにより狭隘通路を通過する回転移動アルゴリズムを 提案する．ただし本報告では準静的な動作のみを対象とするた めロボットの倒立制御を考慮しない。そのため, ロボットは狭 鄎部を構成する壁面に寄り掛かるものとして, その側壁面は口 ボットの倒れこみを支えることが可能でロボットの回転を妨げ ない比較的滑らかな面とする（Fig. 5 (a)）.

\section{1 狭险通路の通過姿勢と回転歩容アルゴリズム}

アスタリスクロボットが壁面に支えられながら直立する場合, 


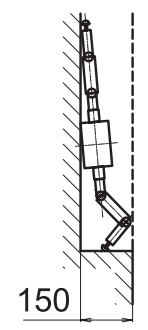

(a)

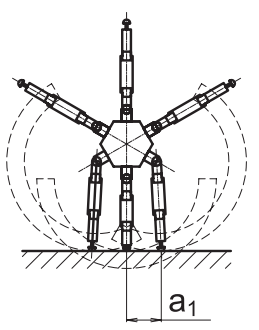

(b)

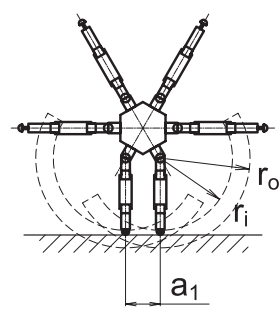

(c)
Fig. 5 Workspace of support legs and Posture of the robot in a narrow lane
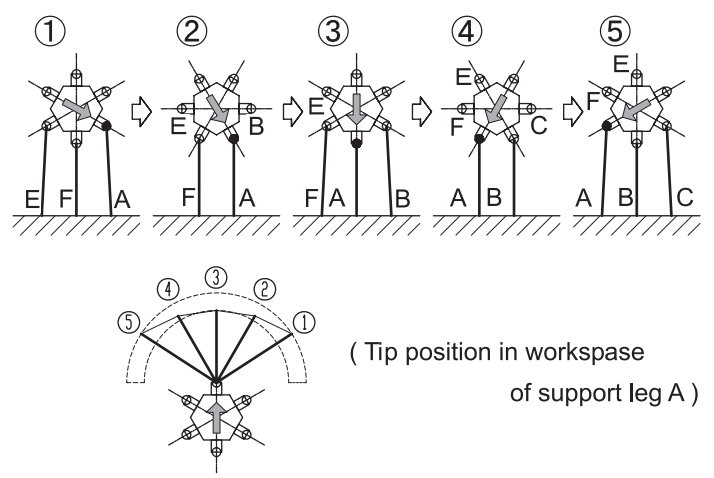

Fig. 6 Rotational gait on a narrow lane

脚が接地できる姿勢は, 脚の動作可能範囲と準静的動作である という条件から， 2 脚または 3 脚で支持するものとなる。この 直立姿勢に抏いて支持脚を屈伸させることにより脚先端位置を 変える, すなわち脚長を変えることによりロボット全体を回転 させて移動を行う。

支持動作可能範囲は，支持脚を屈曲させるにつれて各関節の 負荷トルクが大きくなることから脚長の範囲が規定され, 本報 告で用いるアスタリスクロボット（Fig. 3）の場合には脚を伸ば した状態 $r_{o}=258.5[\mathrm{~mm}]$ から曲げた状態 $r_{i} \simeq 230[\mathrm{~mm}]$ まで の姿勢となる。また脚の接地間隔 $a_{1}$ は, 接地間隔を広くする と脚が開いて根元関節 J1 にかかる負荷が大きくなることから, 隣接する脚の根元間の距離 $100[\mathrm{~mm}]$ としてなるべく J1に負荷 が掛からないように決定した (Fig. 5). この支持動作可能範囲 は Fig. 5 (b), (c) のように脚の進行方向の範囲が狭くなってい るために脚を進行方向に踏み換えることは困難である.

本報告で提案する回転歩容では Fig. 6 の上段に示すように 順次,

(1) A, F, E の 3 脚が支持間隔 $a$ で支持している基準姿勢

(2) 後脚 $\mathrm{E}$ が遊脚となり, 残りの 2 脚 $\mathrm{A}, \mathrm{F}$ により支持・回転 して前進する

(3) 遊脚であった脚 B が接地して前脚となり， B， A， F の 3 脚で支持されている基準姿勢

の動作アルゴリズムをとる. Fig. 6 の下段は Fig. 5 に示した脚の 支持動作範囲内に打ける，ロボット本体側矢印部分から見た支持 脚 $\mathrm{A}$ の各フェーズでの先端位置を示す。ロボットの姿勢は $60^{\circ}$ 回転するごとに同等の姿勢となるため, この動作を脚を順送りに 繰り返すことにより，回転しながら前進移動することができる.

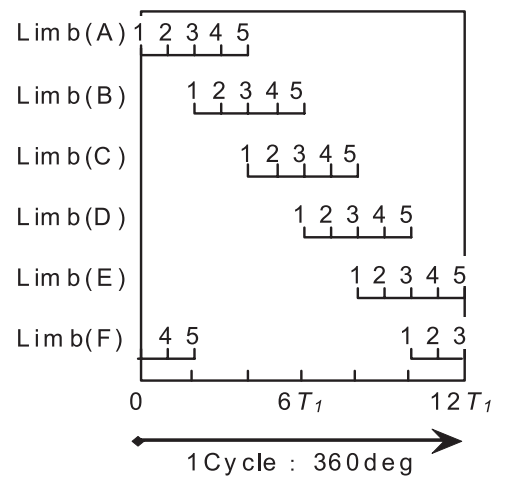

Fig. 7 Diagram of rotational hanging gait

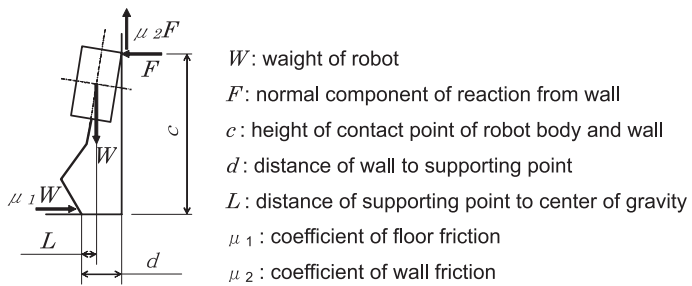

Fig. 8 Friction of support points on a narrow lane

各フェーズ間の移行時間を $T_{1}$ として脚の支持動作をダイヤグ ラムに表すと Fig. 7 のようになり, デューティ比は $1 / 3$ となる.

\section{2 狭险通路における支持脚の摩擦力の条件}

ロボット本体が側壁面に寄り掛かりながら本体下側の脚で支 持・回転移動を行う場合には, 接地支持脚が地面で滑らない条 件が必要となる。

支持脚先端を中心としたモーメントのつり合いは，Fig. 8 から，

$$
W L=F c+\mu_{2} F d
$$

ロボットが地面で滑らないための条件は,

$$
F \leq \mu_{1} W
$$

式（1）（2）より，

$$
\frac{L}{c+\mu_{2} d} \leq \mu_{1}
$$

ロボットと壁面の摩擦項 $\mu_{2} d$ は動作状態によって恋動する. 式 （3）から， $\mu_{1}$ の許容最小值を求めたいので， $\mu_{2}$ を 0 とすると,

$$
\frac{L}{c} \leq \mu_{1}
$$

となる.式（4）に実際のロボットの寸法值 $L \simeq 25[\mathrm{~mm}]$, $c \simeq 360[\mathrm{~mm}]$ を入れると, 必要な床面との静止摩擦係数は $\mu_{1} \geq 0.07$ 程度となる. 実測による支持脚先端の接地部（ゴ ム）と床面 (木質) との摩擦係数は 0.5 程度であり, 滑らずに 移動姿勢を保つことが可能である.

\section{3 傾斜・凹凸のある狭隘通路への回転歩容の適用条件}

3.1 節では移動する接地面を平坦な面としていたが, 実環境 においては平坦な水平面とは限らず，傾斜あるいは凹凸をもつ 不整な面であることも考えられる。この場合の動作可能条件 を考察する。側転姿勢における各支持脚の接地位置の最大高低 差 $H_{1}=r_{o}-r_{i}$ は支持脚の支持動作可能範囲（Fig. 5）によ 
り制限されており，Fig. 3 に示したアスタリスクロボットでは $H_{1} \simeq 30[\mathrm{~mm}]$ となる. 単独の段差や凹凸部の場合には隣接す る支持脚の最大高低差が $H_{1}$ となるが, 傾斜面の場合には前脚 と後脚の高低差が $H_{1}$ 以下であることが必要である（Fig. 9). このときの前後脚の接地間隔 $2 a_{1}$ は $200[\mathrm{~mm}]$ であり, 支持・ 移動姿勢をとることが可能な最大傾斜角 $\theta_{3}$ は

$$
\theta_{3}=\tan ^{-1}\left(\frac{H_{1}}{2 a_{1}}\right)
$$

となり, 脚の支持可能範囲の寸法比率を $R=r_{i} / r_{o}$ とすると

$$
\theta_{3}=\tan ^{-1}\left(\frac{r_{o}}{2 a_{1}}(1-R)\right)
$$

と表すことができる。 $\theta_{3}$ はおよそ $8.5[\mathrm{deg}]$ となる.

\section{4 狭险通路における回転歩容の検証・確認}

狭盆通路通過移動アルゴリズムをロボットに実装し, 動作の 確認を行った。本体を回転させ支持脚を順次移動させていくこ とにより, 本体が水平の通常の移動姿勢では通過することがで きない狭い幅の通路を移動することが可能であることが検証で きた. Fig. 10 に動作フェーズ(1)から (3)までの動きの例を示す. また前節の傾斜・凹凸面への適用についてもほぼ前節どおりの 条件の範囲で動作可能なことを確認した.

\section{4. ケーブル懸垂移動と回転歩容}

前章では壁に挟まれた狭盆通路での移動について述べたが, 本章ではロボットが移動する狭盆足場環境として水平に張り渡 した 1 本のケーブルを足場とする回転歩容を提案する.

ロボットによる周辺環境の探索行動においては，地上の低い 場所を移動することによる情報収集だけではなく上方から俯瞰 することが可能であれば情報量は飛躍的に増大すると考えられ る.ロボットを三次元的に移動させる方法としては, 飛行によ る空間移動が提案されているが [12] [13], 建物内などの狭い空 間での移動が難しいことや, 飛行に特化しているため移動作業 を行うことができないなどの問題がある.

筆者らは前述の Fig. 2 のように, アスタリスクロボットの三
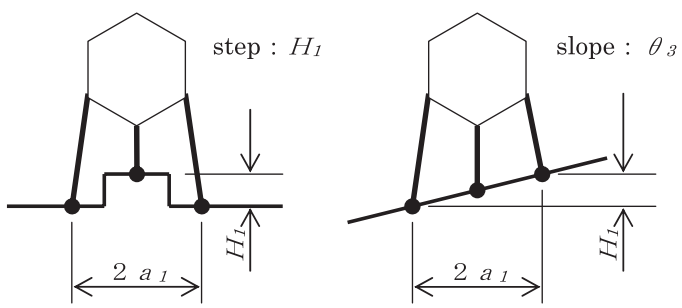

次元空間内での移動方法として，グリッド天井を足場とした懸 垂移動動作を提案しているが，この場合には格子状の金属枠あ るいはそれに類する足場があらかじめ具備されている限定され た環境内での適用となる.

そこで格子状足場よりも比較的簡単に設置することが可能な ケーブルを足場とする移動動作を考える。この場合にはロボッ トがケーブルの上側に乗った状態での姿勢の維持は困難なこと から，ケーブル下側への懸垂姿勢を取るものとする.

このように頭上の支持部を利用して懸垂移動する他の例とし て 2 本の腕を用いてロボットの重心を動的に制御しながら移動 する方法などが提案されているが [14] [15], これには高速な実 時間処理が必要である. 本報告では動作の各時点で安定状態を 保ちながら移動する準静的な動作, すなわち高速な実時間処理 を行うことなく簡単な動作パターンの繰り返しで移動する方法 として回転歩容アルゴリズムによる移動を提案する.

\section{1 ケーブル懸垂姿勢}

ロボットを準静的に移動させる場合には，つねに 2 脚以上で 懸垂支持する必要がある.

本報告で提案するケーブル懸垂においては，脚の先端に駆動 部を持つケーブル把持機構は用いず，Fig. 11 (a)に示すような 半球一円盤状の先端を用いる。 これは先に示した Fig. 2 のグリッ ド天井の移動動作において提案した形状であり, 半球部分が歩 行時の接地用の先端ゴム, 円盤平面部分が全方向に引っ掛けが 可能な懸垂用のフックである. このフック部をケーブルに引っ 掛けることにより懸垂する。このフックがケーブルから外れず に掛けられる角度 $\phi$ (ケーブルの軸方向からみた懸垂支持脚が 鉛直線となす角度）は脚の動作範囲によって規定されることか ら, Fig. 11 (b) に示す 20 [deg] 以上 55 [deg] 以下と決定した.

脚の動作範囲内での懸垂可能範囲は Fig. 12 に示すような扇 形領域となり, 隣接する各脚の動作範囲から 2 脚または 3 脚で 懸垂する基本姿勢（Fig. 12 (b)，(c)）が得られる.

\section{2 ケーブル懸垂回転歩容}

ケーブル懸垂の場合においても前述の狭隘部の移動と同様に, 本体を回転させることにより支持脚（支持位置）を移してロボッ ト本体を移動させる回転歩容アルゴリズムを適用することがで きる. 本体を回転させながら移動する順序はFig. 13 の上段に 示すようになり, 支持脚姿勢は回転に伴い(1) 3 脚 $\rightarrow$ (2) 2 脚 $\rightarrow$ (3) 3 脚となる. Fig. 13 の下段は Fig. 12 に示した脚の懸垂可能範囲 内における, ロボット本体側矢印部分から見た支持脚 A の各 フェーズでの先端位置を示す，回転に伴い各脚が順次同じ動作 を繰り返すことにより移動できる。この場合の支持脚のダイヤ グラムは Fig. 7 と同じものとなり, 脚のデューティ比について

Fig. 9 Slope and step in a narrow lane

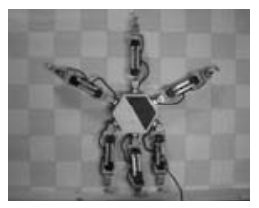

(1)
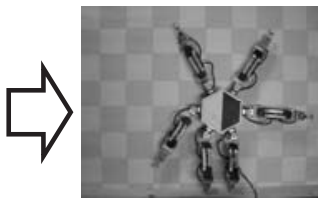

Fig. 10

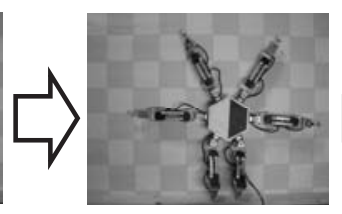

(2)
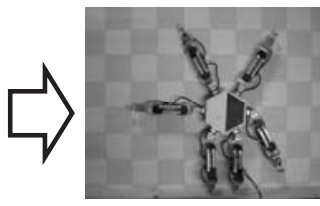

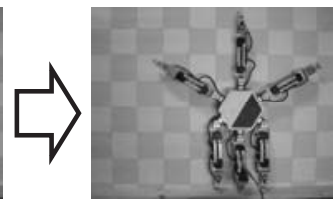

(3) 


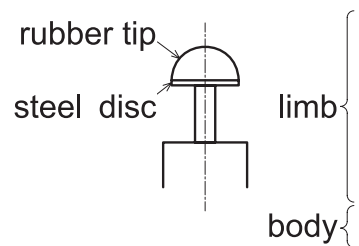

(a)

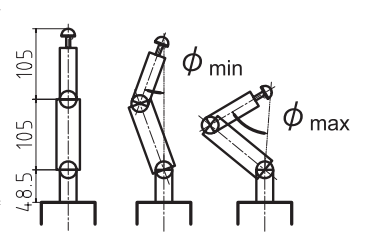

(b)
Fig. 11 End effector hook and Posture of a support limb

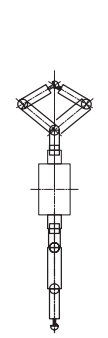

(a)

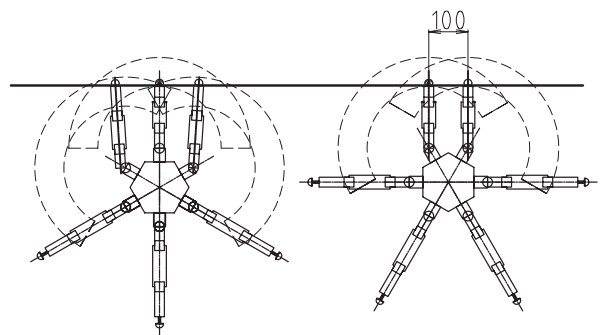

(b) (c)
Fig. 12 Workspace of support legs and Posture of the robot of Hanging on a cable

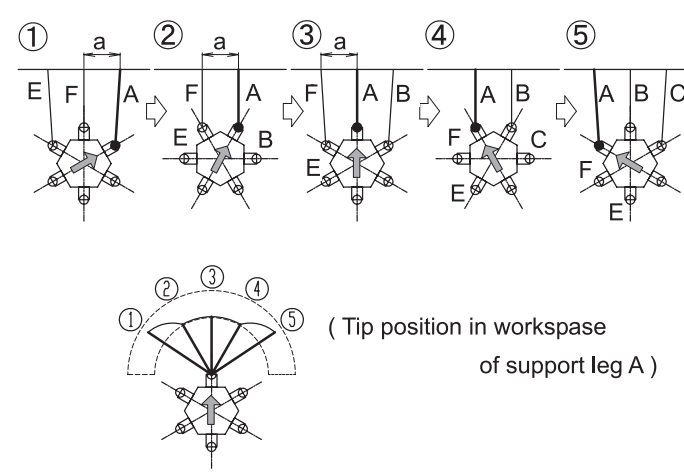

Fig. 13 Rotational hanging gait below a cable

も前述の狭盆通路における回転歩容と同様に $1 / 3$ となる.

4.3 傾斜・屈曲するケーブルへの懸垂回転歩容の適用条件 前節に打いては，支持ケーブルを水平としたが，実際にはケー ブルが水平であるとは限らず，またケーブルにたわみも生じる。 ケーブルの傾斜角度が大きい場合には, ケーブル上でロボット支 持部が滑ってしまい移動できなくなる，本節ではケーブルの傾斜 およびロボットの自重によるケーブルの屈曲の条件を考察する.

まずはケーブルが傾斜している場合， ロボットの懸垂部分で のケーブルの傾斜角度が $\theta$ の場合を考える (Fig. 14)。 ロボッ トとケーブルの静止摩擦係数を $\mu_{0}$ とすると, 摩擦角 $\theta_{0}$ との 関係から，ロボットが滑らない傾斜角度の条件は,

$$
\mu_{0}=\tan \theta_{0}>\tan \theta
$$

となる $[16]$. 使用している鋼線ケーブルと脚の先端フックとの静 止摩擦係数は $\mu=0.2$ 程度であり, 摩擦角は打よそ $\theta_{0}=11$ [deg] となる。実際のロボットでは, $\theta=10[\mathrm{deg}]$ 程度であり, 上式 （7）に近い值をとることが確認できた.

次にケーブルにたわみがある場合を考える。ケーブルのたわ み形状は理想的には懸垂線となるが，使用するケーブルの非線

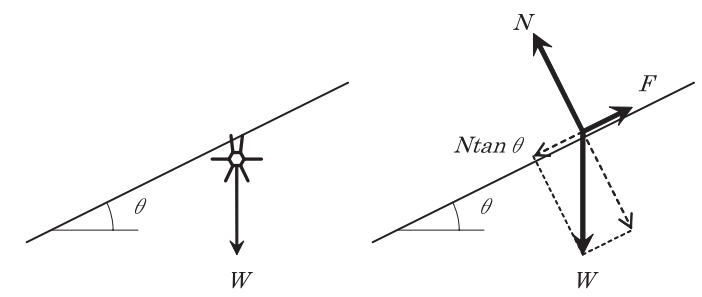

Fig. 14 Friction angle of a cable

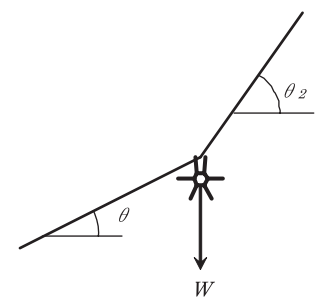

(a)

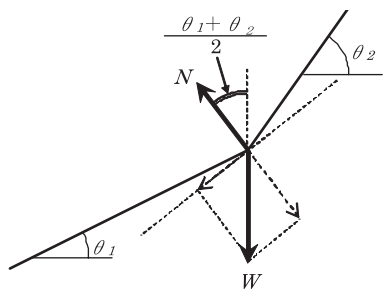

(b)
Fig. 15 Friction on bending point of a cable

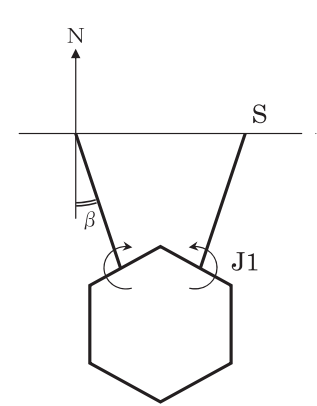

(a)

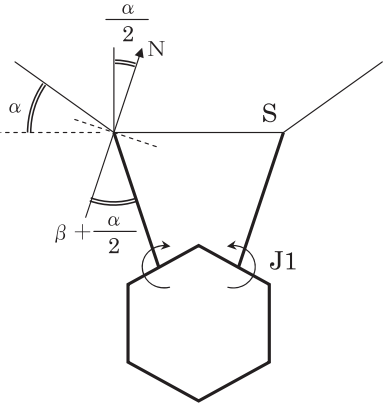

(b)
Fig. 16 Friction of support limbs and Torque of the Proximal joint

形伸びその他不確定な要素も多い，本項では支持部での摩擦を 問題にしているので，ロボット近傍では直線形状であると仮定 しロボット前後のケーブルの傾斜角度のみを考えるものとする。 懸垂するロボットの重量 $W$ により，ケーブルはFig. 15 (a)の ように支持位置で折れ曲がった状態になる。 ケーブル角度 $\theta_{1}$, $\theta_{2}$ とすると, 脚先端が接触しているロープ屈曲部での垂直抗力 $N$ の方向は, 接触部の面積が小さく接触部分での応力分布が無 視できるとすると Fig. 15 (b)のように $\left(\theta_{1}+\theta_{2}\right) / 2$ となるので, この場合ケーブルの摩擦角と静止摩擦係数 $\mu_{0}$ の関倸は,

$$
\mu_{0}=\tan \theta_{0}>\tan \left(\frac{\theta_{1}+\theta_{2}}{2}\right)
$$

となる，実際のロボットにおいてすべりを生じなかった限界角 度は $\theta_{1}=5[\mathrm{deg}], \theta_{2}=15[\mathrm{deg}]$ 程度であったことから, 上式 （8）の関倸が近似的に成り立つことが確認できた。

\section{4 ケーブル懸垂姿勢における支持脚先端の摩擦力と関節 トルクについて}

ロボットが水平なケーブルに懸垂している場合，懸垂支持部 の摩擦力が大きい場合には, 支持部 S に水平力を与えなくても すべることなく支持位置を保つことができる（Fig. $16(\mathrm{a}))$.こ 


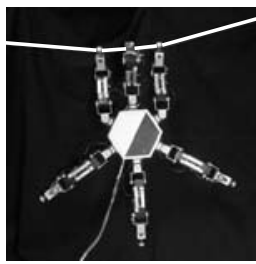

(1)

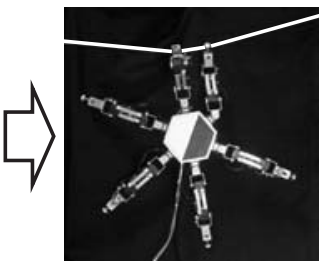

Fig. 17 Rotational hanging gait below a cable by ASTERISK
のときには支持脚の根元の J1 の関節トルクは不要となり, 中 間関節 J2 と先端関節 J3 による脚の伸縮のみで回転移動を行う ことができる。このときの支持脚の懸垂角度 $\beta$ の条件は，

$$
\mu_{0}=\tan \theta_{0}>\tan \beta
$$

となる。この条件は水平な壁面棚部での懸垂姿勢の場合にも同 様に適用される。

また，ケーブルにロボットの重量によるケーブルの屈曲があ る実際の場合には，傾斜角 $\alpha$ により支持面が傾いたものとみな せるので (Fig. 16(b)), 式（9）は

$$
\mu_{0}=\tan \theta_{0}>\tan \left(\beta+\frac{\alpha}{2}\right)
$$

となる.この条件の下では支持脚の根元の $\mathrm{J} 1$ 関節のトルクは 0 となる。

\section{5 ケーブル懸垂移動の検証・確認}

ケーブル懸垂アルゴリズムをロボットに実装し動作の確認を 行った. Fig. 17 に回転歩容のフェーズ(1)から (3)までの動きの 例を示す。実際の動作の場合には前述のケーブルのたわみや支 持部での摩擦力等も考慮する必要はあるが, 移動アルゴリズム としては問題なく機能することが確認できた.

\section{5. 壁面棚部の懸垂移動}

前 2 章では狭盆部やケーブル懸垂姿勢での回転歩容を提案し たが，本章ではそれらの中間的な移動状態として壁面や傾斜面 にあるロボット本体が乗ることができないような狭い段差を足 場とする移動について検討する。このような移動は，建造物の 壁面にある梁を足場として移動する場合や散乱した瓦碟の稜線 上での移動の場合などに適用することができる.

壁面棚部を足場としてロボット本体を垂直に立てた懸垂姿勢 を取ることによってロボットを支え，この姿勢において回転歩 容を適用することにより移動するものである（Fig. 18）.

\section{1 壁面棚部での懸垂姿勢と回転歩容}

棚部の端に脚を掛けて懸垂移動する場合には, 脚先端が棚面 に確実に接地する必要がある。棚面と脚のなす角度が浅いと脚 先端が接地せずに脚側面が棚面に接触してしまうことから, 棚 面と脚のなす角度 $\beta$ を $20[\mathrm{deg}]$ 以上とする（Fig. 19(a)）。 こ の脚先端の接地可能角度をとり得る脚の動作範囲は Fig. 19 (b), (c) のような扇形領域となり, 隣接する各脚の動作範囲から 2 脚 または 3 脚で懸垂することが可能である。しかしながらこの懸 垂姿勢においては脚先端位置が脚根元の $\mathrm{J} 1$ 関節による特異点の 近傍に位置しており，また隣接する脚との間隔が短く脚同士の 干渉が生じることから, 脚先端の進行方向の動作範囲は極端に

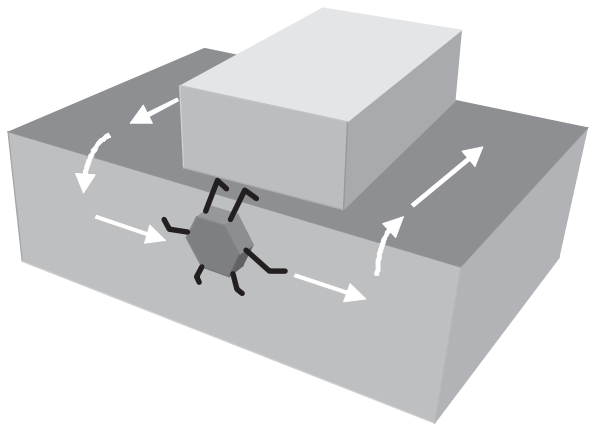

Fig. 18 Moving on a narrow shelf of a cliff

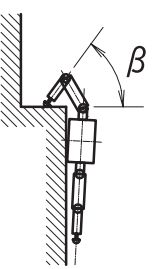

(a)

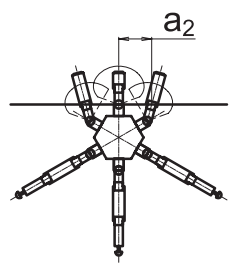

(b)

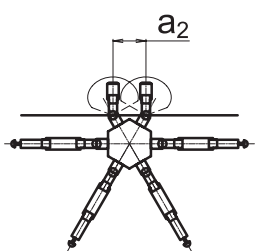

(c)
Fig. 19 Workspace of support legs and Posture of the robot of hanging on a narrow shelf

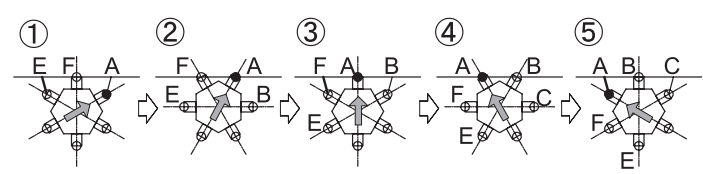

Fig. 20 Rotational hanging gait on a narrow shelf

狭いものとなっており, 本体姿勢が変わらない状態では脚を踏 み換えて移動するためのストロークがとれない，このため，ロ ボット本体を回転させず支持脚を順送りに進めていく歩容は困 難である.

壁面棚部の移動に懸垂回転歩容を適用する場合（Fig. 20）に おいては支持脚のダイヤグラムは Fig. 7 と同じものとなり, 脚 のデューティ比も同様に $1 / 3$ となる.

\section{2 壁面棚部における支持脚の摩擦力の条件}

棚面を足場として懸垂する場合には，接地部が棚面から滑り 落ちない条件が必要となる。

支持脚先端を中心としたモーメントのつり合いは，Fig. 21 から，

$$
W L=F c+\mu_{4} F d
$$

ロボットが棚部を滑り落ちないための条件は, 


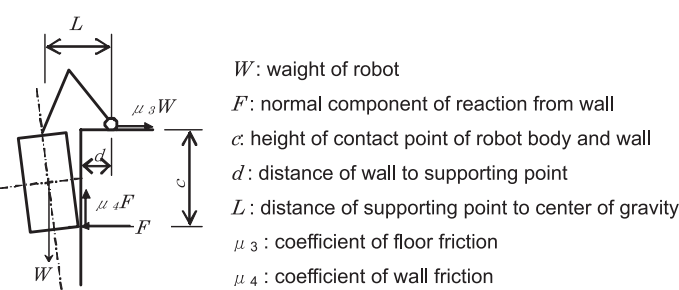

Fig. 21 Friction of support points on a cliff
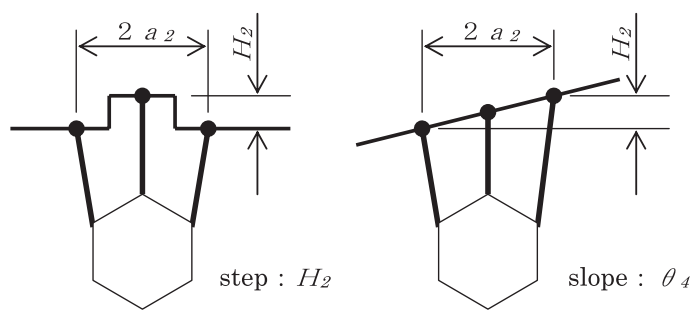

Fig. 22 Slope and step of a narrow shelf

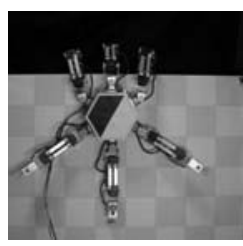

(1)

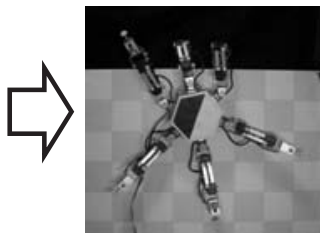

$\mu_{3} W$

$$
F \leq \mu_{3} W
$$

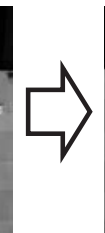

(2)
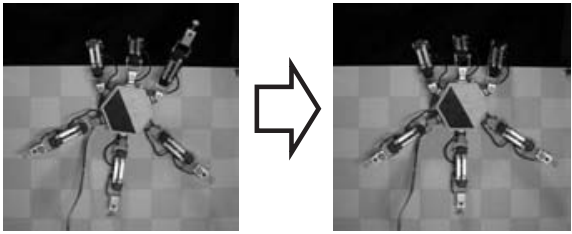

(3)
式（11）（12）より,

$$
\frac{L}{c+\mu_{4} d} \leq \mu_{3}
$$

ロボットと壁面の摩擦項 $\mu_{4} d$ は動作状態によって恋動する. 式 (13) から, $\mu_{3}$ の許容最小值を求めたいので, $\mu_{4}$ を 0 とすると,

$$
\frac{L}{c} \leq \mu_{3}
$$

となる. 式（14）に実際のロボットの寸法值 $L \simeq 105[\mathrm{~mm}]$, $c \simeq 170[\mathrm{~mm}]$ を入れると, 棚面で必要な静止摩擦係数は $\mu_{3} \geq$ 0.6 程度となる。これは支持面に接する脚先端の材質を選ぶこ とにより実現可能な值であり，滑落せずに移動姿勢を保つこと が可能である.

5.3 傾斜・凹凸のある壁面棚部への懸垂回転歩容の適用条件

5.1 節では移動する棚面を平坦な面としていたが, 実環境に おいては平坦な水平面とは限らず，傾斜あるいは凹凸をもつ不 整な面であることも考えられる。この場合の動作可能条件を考 察する. 壁面懸垂姿勢における各支持脚の接地位置の最大高低 差 $H_{2}$ は, 支持脚の懸垂可能範囲（Fig. 19）により制限されお よそ $H_{2}=40[\mathrm{~mm}]$ となる. 単独の段差や凹凸部の場合には隣 接する支持脚の高低差が $H_{2}$ となるが, 傾斜面の場合には前脚 と後脚の高低差が $H_{2}$ 以下であることが必要である（Fig. 22）. このときの前後脚の接地間隔 $a_{2}$ は $100[\mathrm{~mm}]$ であり, 懸垂姿勢 をとることが可能な最大傾斜角は

$$
\theta_{4}=\tan ^{-1}\left(\frac{H_{2}}{2 a_{2}}\right)
$$

となることからおよそ $11[\mathrm{deg}]$ となる。

\section{4 壁面棚部の懸垂移動の検証・確認}

壁面棚部での回転歩容アルゴリズムをロボットに実装し, 動 作の確認を行った. Fig. 23 に動作フェーズ(1)から(3)までの動 きの例を示す．前章までの回転歩容と同様にアルゴリズムは問 題なく機能していることが確認できた。 また実際の支持面に前
項の凹凸あるいは傾斜を持たせた場合でも, 問題なく動作可能 なことを確認した.

\section{6. 回転歩容とウェーブ歩容の比較}

これまで示した移動姿勢においては, 支持脚の踏み換え動作 が困難なことから回転歩容を提案しこれの実証を行った。

しかしながら 4 章のケーブル懸垂姿勢においては Fig. 12 (a) のように脚をケーブルの両側から交互に掛けることが可能であ り, この場合には隣接する脚同士が干渉しないので脚前進時に 脚を交差させて移動することができる。

\section{1 ケーブル懸垂 3 脚ウェーブ歩容}

ロボットを準静的に移動させる場合には，つねに 2 脚以上で 懸垂支持する必要がある，本体姿勢一定のまま準静的に移動す る方法としては, Fig. 24 のように 3 脚支持の状態で後方の脚 から移動ストローク分の距離 $b$ を踏み換えていく歩容が考えら れる。この歩容を本報告では 3 脚ウェーブ歩容と定義する（以 降ウェーブ歩容と記述).

動作アルゴリズムは順次,

(1) $\mathrm{A} ， \mathrm{~B} ， \mathrm{C}$ の 3 脚で支持されている基準姿勢.

(2) 後脚 $\mathrm{C}$ が遊脚となり前方へ踏みかえ, ロボットは残りの 2 脚 $\mathrm{A} ， \mathrm{~B}$ により前進.

(3) 中央脚 $\mathrm{B}$ が遊脚となり前方へ踏みかえ, ロボットは残りの 2 脚 $\mathrm{A}, \mathrm{C}$ により前進.

(4) 前脚 $\mathrm{A}$ が遊脚となり前方へ踏みかえ, ロボットは残りの 2 脚 $\mathrm{B}, \mathrm{C}$ により前進, $\mathrm{A}, \mathrm{B}, \mathrm{C}$ の 3 脚で支持されている 基準姿勢へ戻る.

となる。またウェーブ歩容においては， 6 脚のうち 3 脚 $\mathrm{A}, \mathrm{B}$, Cのみしか使用しない.

各フェーズ間の移行時間を $T_{2}$ として脚動作をダイヤグラム に示すと Fig. 25 となり, デューティ比は $2 / 3$ となる.

Fig. 26 に支持脚の各関節のトルクのシミュレーション結果 を示す。重心近傍の上部に位置し, 脚の根元関節から先端支持 部までの距離が短い中央脚 $\mathrm{B}$ の関節トルクが他の脚よりも大き 


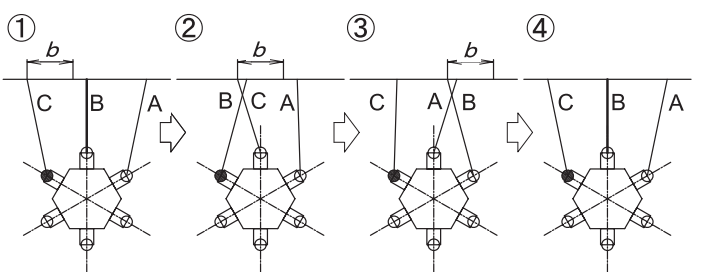

Fig. 24 Wave hanging gait below a cable
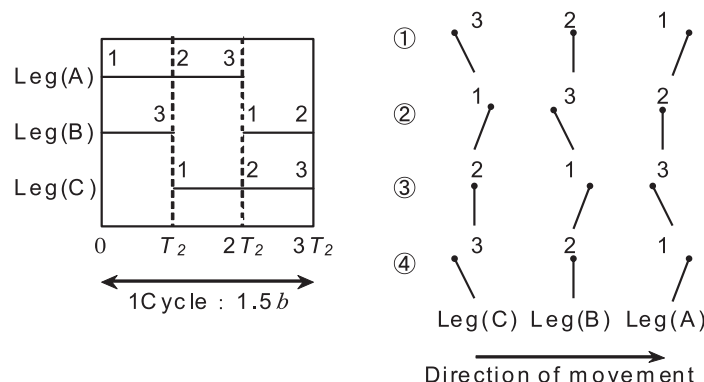

Fig. 25 Diagram of wave hanging gait
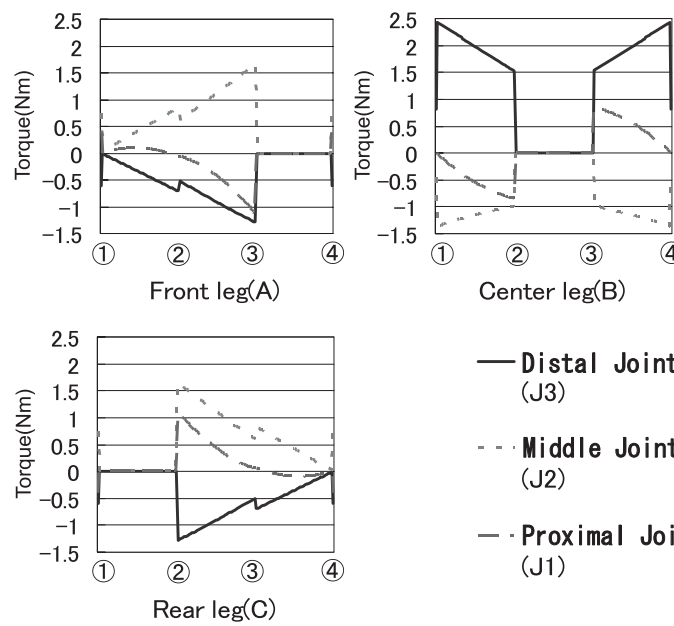

-Distal Joint (J3)

- Middle Joint

(J2)

- - Proximal Joint

(J1)

Fig. 26 Torque data of wave gait simulation

くなっており，負荷が中央脚 B に集中していることが分かる. 各関節の角速度（Fig. 27）についてはロボットは支持脚の摇動 により前進することから根元関節が最も大きく, 脚の伸縮は小 さいことからほぼ一定の速さで動いていることが分かる.

\section{2 ケーブル懸垂におけるウェーブ歩容と回転歩容の比較}

Fig. 28 にケーブル懸垂回転歩容における支持脚 A の各関節 のトルクのシミュレーション結果を示す。回転歩容では各脚が 順次同じ動作を行うことから，各支持脚の負荷トルクは同じも のとなる. 回転移動時には, フェーズ(3)脚の踏み換え前後の 2 脚支持のときに中央部の脚がロボット重心の直上に位置しロ ボット重量のすべてを支持することになるため, 中央脚の負荷 トルクが最大となっている。また支持脚は鉛直に近い姿勢であ ることから根元の関節 J1 の負荷トルクは全期間でほぼ 0 とな る. 各関節の角速度 (Fig. 29) については回転運動に伴う脚の 伸縮が大きいことから, 中間関節 $\mathrm{J} 2$ の角速度が大きいものと なっている。

各歩容における移動速度は, ウェーブ歩容の場合には同じ姿
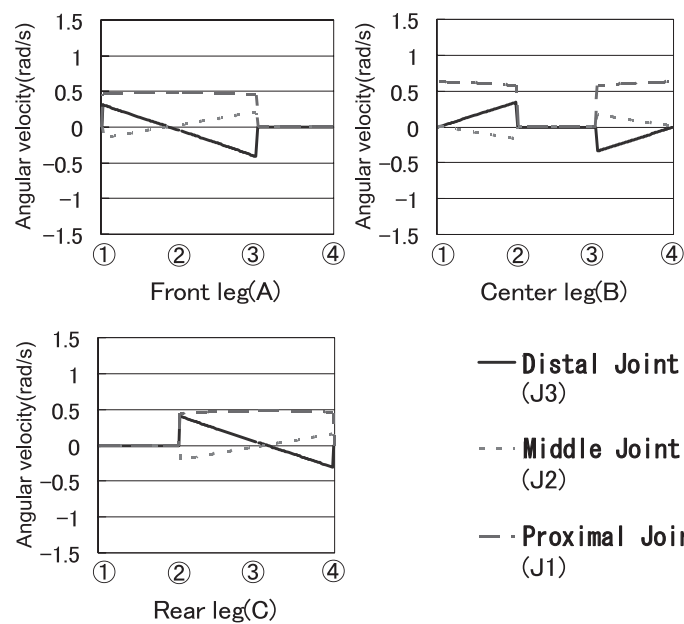

—Distal Joint (J3)

- - Middle Joint (J2)

$-\cdot$ Proximal Joint (J1)

Fig. 27 Angular velocity data of wave gait simulation

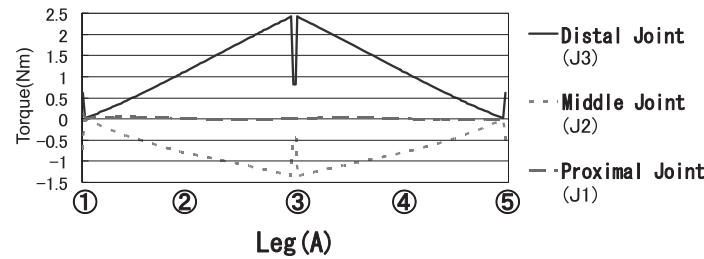

Fig. 28 Torque data of rotational gait simulation

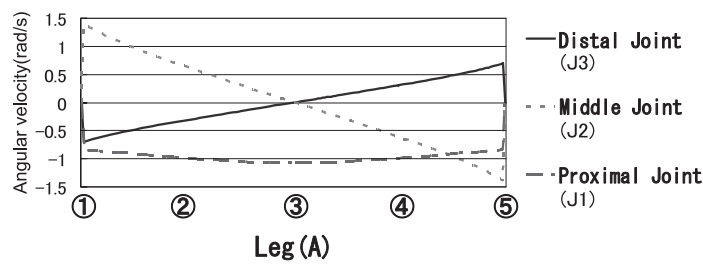

Fig. 29 Angular velocity data of rotational gait simulation

勢に戻る (1)〜 (4)の 3 周期（3T 2 時間）の間に距離 $1.5 b$ 移動す る. 回転歩容の場合には $60^{\circ}$ 回転して同等の姿勢となる (1) (3) の 2 周期 $\left(2 T_{1}\right.$ 時間）の間に脚の支持間隔（歩幅）分の距離 $a$ 移動する。 ウェーブ歩容の場合の単位時間 $T_{2}$, 回転歩容の場 合の単位時間 $T_{1}$ での脚先端の移動量はいずれも $100[\mathrm{~mm}]$ 程 度（脚の中間関節 $J 2$ で $30^{\circ}$ 程度）となるため, 簡単化のた め $T_{1}=T_{2}=T$ とし, 各歩容での 1 動作当たりの単位移動 量 $a, b$ についても $a=b=L$ として比較を行うと, ウェーブ 歩容での速度は $V_{2}=1.5 L / 3 T=L / 2 T$, 回転歩容の場合には $V_{1}=L / 2 T$ となり，移動速度は同じとなる．

また支持脚の各関節卜ルクおよび角速度を比較すると, ウェー ブ歩容の場合には, 中央脚 B にロボットの重量が集中し, その 根元関節 J1 も移動方向に大きく摇動することから負荷トルク および角速度は大きなものとなっている。 これに比べて回転歩 容の場合には支持点の間隔 $a$ が脚の根元の間隔と同じで, 脚自 身の摇動によるロボットの重心移動はなく支持脚はほぼ鉛直の 状態で自重を支えていることから，根元関節 J1 のトルクはほ ぼ 0 となる。ただし重心の直上部に支持点が来る姿勢(3の前後 では中央脚に掛かる負荷トルクは大きくなるため, このときの 中央脚の中間関節 $\mathrm{J} 2$, 先端関節 $\mathrm{J} 3$ の最大トルクはウェーブ歩 
容の中央脚 B と同様の大きさとなっている. そして回転歩容で は脚の伸縮が大きいことから中央関節 J2 の角速度はウェーブ 歩容の 2 倍程度となっている.

しかしながら回転歩容アルゴリズムでは回転により 6 脚すべ てを均等に使用して順次支持脚が入れ替わり遊脚の割合も比較 的長いことから（デューティ比は $1 / 3$ ), ウェーブ歩容と異なり 特定の脚への負荷の集中は起こらず，また各脚のアクチュエー 夕に長時間の連続負荷を与えることなく懸垂移動動作を実現す ることができる。

\section{7. おわりに}

本報告では，回転対称性を持つアスタリスクロボットの特徴 を活かし，ロボットが側転することにより狭险通路，ケーブル あるいは壁面棚部などを足場として移動するアルゴリズムを提 案, 実証を行った。これら 3 種類の異なる移動環境に適用する 回転歩容アルゴリズムは（脚の接地姿勢は異なるが）同一のも のである

棚部や狭隘部での移動のように支持脚の動作範囲が限定され るため脚の踏み換え動作が困難な姿勢においてもロボットを容 易に移動させることができ，また回転移動で各脚を順次支持脚 として使用することによりすべての脚に均等に負荷を分散しな がら移動することが可能であることを示した。

今後は本報告で提案した回転移動アルゴリズムだけではなく, 不整な傾斜面など車輪移動での高効率動作が難しい環境での多 脚ロボットによる積極的な本体姿勢変化を利用した歩容につい て検討を進めていきたい

\section{参 考 文 献}

[1 ] J. Casper and R.R. Murphy: "Human-Robot Interactions During the Robot-Assisted Urban Search and Rescue Response at the World Trade Center," IEEE Transactions on Systems, Man, and Cybernetics. Part B, Cybernetics, vol.33, no.3, pp.367-385, 2003.

[2] J. Carlson, R.R. Murphy and A. Nelson: "Follow-up analysis of mobile robot failures," Proceedings of the 2004 IEEE International Conference on Robotics and Automation, vol.5, pp.4987-4994, 2004.

[ 3 ] A. Wolf, H.H. Choset, B.H. Brown and R.W. Casciola: "Design and control of a mobile hyper-redundant urban search and rescue robot," Advanced Robotics, vol.19, no.3, pp.221-248, 2005.

[4] 広瀬, 塚越, 米田: “不整地における歩行機械の静的安定性評価基準”, 日本ロボット学会誌, vol.16, no.8, pp.1076-1082, 1998 .

[5] K. Yoneda, K. Suzuki and Y. Kanayama: "Gait planning for versatile motion of a six legged robot," Proceedings of the 1994 IEEE International Conference on Robotics and Automation, pp.1338-1343, 1994

[6] 小谷内, 安達, 新井: “腕・脚統合リムメカニズム—腕転用脚機構の運動 学解析—”, 日本ロボット学会誌, vol.14, no.7, pp.968-976, 1996.

[7] T. Takubo, T. Arai, K. Inoue, H. Ochi, T. Konishi, T. Tsurutani, Y. Hayashibara and E. Koyanagi: "Integrated Limb Mechanism Robot ASTERISK," Journal of Robotics and Mechatronics, vol.18, no.2, pp.203-214, 2006.

[8] 程島, 土居, 福田, 広瀬, 岡本, 森 : “4 足歩行型法面作業ロボット TITAN XI の開発一基本設計と脚機構の動作実験—”, 日本ロボッ 卜学会誌, vol.23, no.7, pp.847-857, 2005.

[9] S. Fujii, K. Inoue, T. Takubo and T. Arai: "Climbing up onto Steps for Limb Mechanism ROBOT "ASTERISK"," 23rd In- ternational Symposium on Automation and Robotics in Construction, pp.225-230, 2006.

[10] 米田，関山，長谷川，福田：“重力モーメント考慮の姿勢制御による マルチロコモーションロボットを用いての垂直梯子登り運動”, 日本 機械学会論文集 (C 編), vol.75, no.751, pp.524-531, 2009.

[11] 前, 高橋, 新井, 井上, 小谷内：“腕脚統合型ロボットの全方向移動”, 日本ロボット学会誌, vol.22, no.3, pp.329-335, 2004.

[12] A. Ollero and L. Merino: "Control and perception techniques for aerial robotics," Annual Reviews in Control, vol.28, no.2, pp.167-178, 2004.

[13] W. Wang, G. Song, K. Nonami, M. Hirata and O. Miyazawa: "Autonomous Control for Micro-Flying Robot and Small Wireless Helicopter X.R.B," Proceedings of the 2006 IEEE/RSJ International Conference on Intelligent Robots and Systems, pp.2906-2911, 2006.

[14] H. Kajima, M. Doi, Y. Hasegawa and T. Fukuda: "A study on brachiation controller for a Multi-locomotion Robotrealization of smooth, continuous brachiation," Advanced Robotics, vol.18, no.10, pp.1025-1038, 2004.

[15] 梶間, 長谷川, 福田：“マルチロコモーションロボットによるブラキ エーション運動制御—エネルギーに基づく Swing-back 制御—”，日 本ロボット学会誌, vol.23, no.8, pp.993-1001, 2005.

[16] 奥田, 真室 : 基礎物理学 上巻. p.63, 内田老鶴围新社, 1982.

\section{付録 A. 3 脚支持姿勢におけるウェーブ歩容について}

3 章および 5 章においてはアスタリスクロボットの動作範囲 の制約から脚の踏み換えによるウェーブ歩容が適用できなかっ たが，支持脚の動作範囲が十分取れるならば直立姿勢でのウェー ブ歩容も可能である. 例えば Fig. 30 のように各脚が移動動作 中に干渉しないように配置されたロボットを仮定した場合，(a) 脚がロボットの本体上側にあって懸垂する場合でも (b) 本体下側 にあって支持する場合でも同じ動作アルゴリズムが適用できる. ただし 6 章で指摘したようにウェーブ歩容での中央支持脚への 負荷の集中，使用しない脚があるなどの問題点は変わらない.

この場合のロボットの脚動作は Fig. 31 となって 6.1 節で述 ベた動作と同じものとなる．脚のストロークを $b$ とすると 1 動 作サイクルでの移動距離は $1.5 b$ であり支持脚のデューティ比も 同様に $2 / 3$ となる.

\section{付録 B. 3 脚支持姿勢における中央脚の集中負荷と脚の 踏み換えタイミングについて}

前述のウェーブ歩容の場合, Fig. 31 の(1)あるいは(4)での脚の 踏み換え前後の 2 脚支持のときにロボットの重心位置が中央脚 の直下となるため中央脚にロボットの全重量が掛かる。またこ

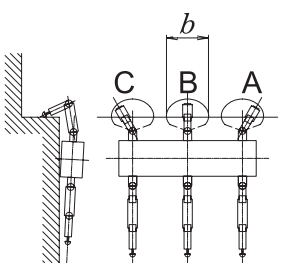

(a)

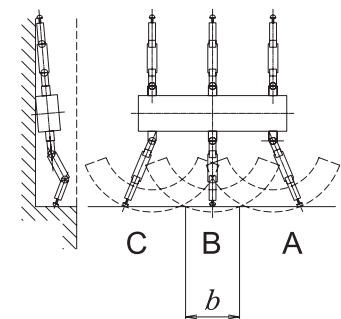

(b)
Fig. 30 Layout of limbs for wave gait 
(1)

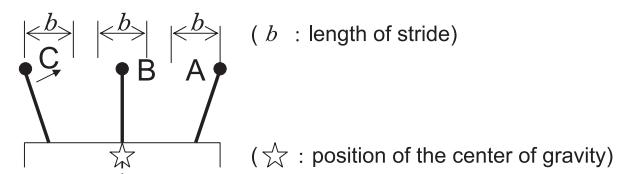

(2)

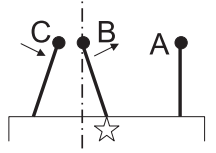

(3)

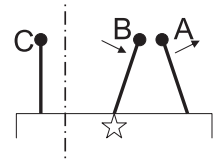

(4)

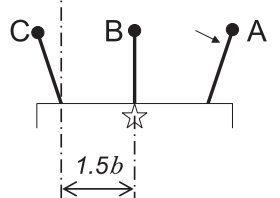

Fig. 31 Motion sequence of limbs for wave gait algorithm

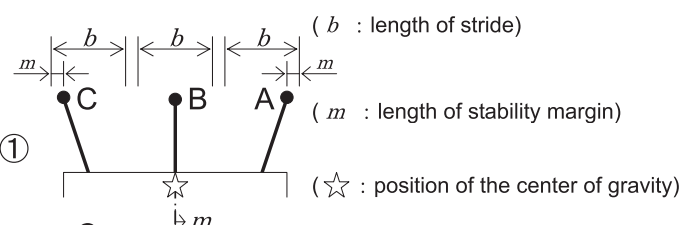

(2)

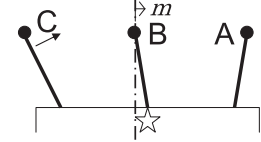

(3)

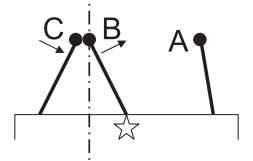

(4)

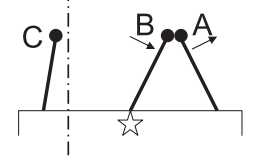

(5)

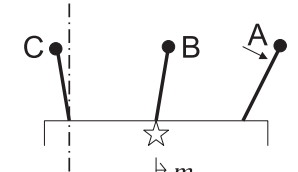

(6)

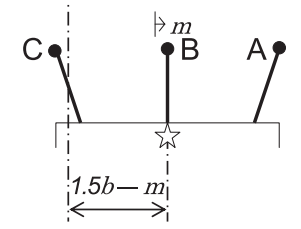

Fig. 32 Step position shift on wave gait

のときには安定余裕も 0 となっている. 脚の踏み換え時には安 定余裕を持ち, 中央脚の負荷集中も減らすことが望ましい。 そ のためには Fig. 32 のように脚の踏み換え時期をずらすことに より距離 $m$ の安定余裕を確保して移動する方法が考えられる. この場合の 1 動作サイクルあたりの移動距離は $1.5 b-m$ とな り, 脚の踏み換え時の重心のシフト量 $m$ の分だけ短くなる.

同様の考え方は回転歩容の場合にも成り立つ. 回転歩容の場合 には支持脚が進行方向に移動する必要はないため, 脚の伸縮方向 の動作範囲に余裕があれば Fig. 13 に示した脚の動作を Fig. 33 に示すように(1)では後脚 E が遊脚となるタイミングを遅らせて

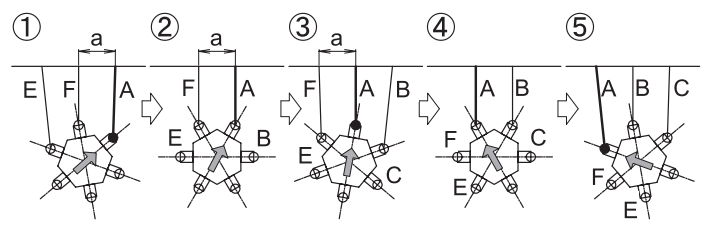

Fig. 33 Step timing shift on rotational gait

$\mathrm{F}$ に負荷が集中しないようにする，(3)では遊脚 B が前脚となる タイミングを早めて A に負荷が集中しないようにする，という 形で脚の踏み換え時期をずらして前後の遊脚を伸ばして接地さ せることにより移動速度を換えることなく安定余裕の確保, 負 荷集中を減らすことが可能となる。

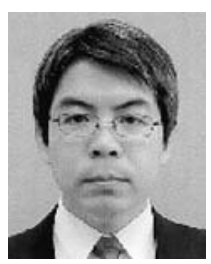

上川健司（Kenji Kamikawa）

1993 年大阪市立大学大学院工学研究科前期博士課 程修了。同年日立造船株式会社入社. 2008 年大阪 大学大学院基礎工学研究科博士後期課程単位取得退 学.

（日本ロボット学会正会員）

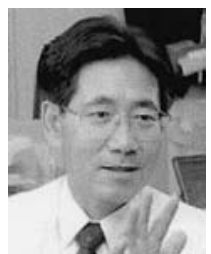

員.
新井健生（Tatsuo Arai）

1977 年東京大学大学院工学系修士課程修了. 工業 技術院機械技術研究所を経て, 現在大阪大学大学 院基礎工学研究科教授. パラレルメカニズム, マイ クロマニピュレーション, 作業移動型ロボット等の 研究に従事. 1986 年 1987 年 MIT 客員研究員. 日本機械学会, 計測自動制御学会, IEEE 等の会

（日本ロボット学会正会員）

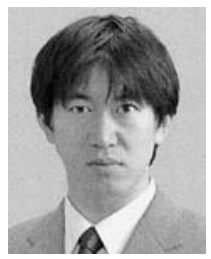

前 泰志 (Yasushi Mae)

1998 年大阪大学大学院工学研究科電子制御機械工 学専攻博士課程修了, 博士 (工学). 同年同大学大 学院基礎工学研究科助手. 2004 年福井大学工学部 助教授. 2007 年 6 月より大阪大学大学院基礎工学 研究科准教授となり現在に至る. ロボットビジョン, 環境知能化，作業移動型ロボット等の研究に従事. 日本機械学会, 情報処理学会, 電子情報通信学会, 日本バーチャルリ アリテイ学会, IEEE の会員.

(日本ロボット学会正会員)

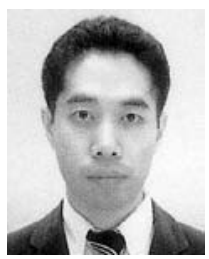

田窪朋仁（Tomohito Takubo）

2003 年 3 月筑波大学大学院工学研究科博士課程修 了. 博士 (工学). 同年 4 月大阪大学大学院基礎工 学研究科特任研究員, 2004 年 7 月大阪大学大学院 基礎工学研究科助手. 2007 年 4 月大阪大学大学院 基礎工学研究科助教.ヒューマノイドロボット, 作 業移動型ロボット, 人間-ロボット協調システムの 研究に従事. 日本機械学会等の会員. （日本ロボット学会正会員）

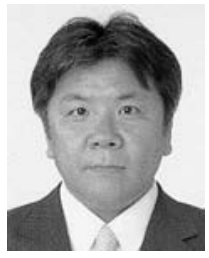

井上健司（Kenji Inoue）

1988 年東京大学大学院工学系研究科修士課程修了. 同年東京大学工学部助手. 大阪大学助手, 講師, 助 教授を経て 2007 年山形大学大学院理工学研究科教 授となり現在に至る。多脚ロボット, ハプテイック デバイス, マイクロマニピュレーション等の研究に 従事. 博士 (工学)。日本機械学会, 計測自動制御 学会等の会員.
（日本ロボット学会正会員） 